\title{
Pollen and Seed Micromorphology of the some Erodium L'Herit (Geraniaceae) Species in Hatay Province
}

\author{
Ahmet İLÇİ⿴囗1 ${ }^{1}$ Meryem GÜNENÇ ${ }^{1}$, Faruk KARAHAN ${ }^{*}$
}

\begin{abstract}
In this study, pollen and seed micromorphology of 7 naturally distrubuted Erodium species (E. acaule, E. amanum, E. botrys, E. cucitarium, E. gruinum, E. malacoides and E. moschatum) in Hatay Province (Turkey) have been studied. Palynological analysis showed that pollen grains were generally medium, spheroidal and spheroidal subprolate, radially symmetrical, tricolporate and reticulate-clavate ornamentation. The seed characters were found ovate-eliptic and oblanceolate in shape, with rugose-foveate, reticulate-foveate and bireticulate-foveate ornamentation. The results demonstrated that characters such as pollen size, pollen shape, seed size, seed shape, seed surface ornamentation and seed cell pattern were found important and useful for the identification of Erodium species investigated.
\end{abstract}

Key Words: Erodium, pollen morphology, seed morphology, SEM, Hatay.

\section{Hatay Yöresinde Yayılış Gösteren Bazı Erodium L'Herit (Geraniaceae) Türlerinin Polen ve Tohum Mikromorfolojileri}

ÖZET: Bu çalışmada, Hatay'da doğal yayılış gösteren 7 Erodium türünün (E. acaule (L.) Becherer \& Thell, E. amanum Boiss \& Kotschy, E. botrys (Cav.) Bertol, E. cucitarium (L.) La'Herit, E. gruinum (L.) La'Herit, E. malacoides (L.) La'Herit ve E. moschatum (L.) La'Herit) polen ve tohum mikromorfolojileri incelenmiştir. Palinolojik analiz sonuçlarına göre polenlerin genellikle radial simetrik, medium büyüklükte, sferoidal ve sferoidal-subprolat şekillerde, trikolporat tipte ve retikulatklavat yüzey ornamentasyonuna sahip olduğu belirlenmiştir. Tohum özellikleri incelendiğinde tohumların ovat-eliptik ve oblanseolat şekillerde ve rugose-foveat, retikulat-foveat ve biretikulatfoveat ornamentasyona sahip olduğu belirlenmiştir. Sonuçlar genel olarak değerlendirildiğinde polen şekli ve boyutu, tohum şekli ve boyutu, tohum yüzey süslemesi ve yüzey epidermal hücrelerin şeklinin incelenen Erodium türlerinin taksonomik ayrımında önemli ve kullanışlı olduğu belirlenmiştir.

Anahtar kelimeler: Erodium, polen morfolojisi, tohum morfolojisi, SEM, Hatay.

\footnotetext{
1 Ahmet İLÇíM (Orcid ID: 0000-0001-8169-2472), Meryem GÜNENÇ (Orcid ID: 0000-0001-7050-3437), Faruk KARAHAN (Orcid ID: 0000-0001-7927-1409), Department of Biology, Hatay Mustafa Kemal University, Hatay, Turkey *Sorumlu Yazar / Corresponding Author: ), Faruk KARAHAN, e-mail: farukkarahan34@gmail.com

This study is a part of Master's thesis of Meryem Günenç. A part of the article was presented as a poster at the 1st International Congress on Plant Biology Congress held in Konya on May 10-12, 2018.
}

Geliş tarihi / Received: 17.04.2019

Kabul tarihi / Accepted: 08.08.2019 


\section{INTRODUCTION}

The genus Erodium L'Herit contains annual, biennial and perennial species and it is distributed on all continents except the Antarctica. Mediterranean region is a major center of diversity of the genus with 74 taxa (Fiz et al. 2006). The genus is divided into two sections (sect. Plumosa and sect. Erodium) and represented by 30 taxa with 25 species in Turkey, and 16 of these taxa are endemic (endemism rate 53\%) (Davis 1967; Davis et al., 1988; Güner, 2000; Yıldırımlı and Doğru Koca, 2004; Günenç, 2015; Oskay et al., 2018). Some Erodium species have been used to bleeding and diarrhea (Baytop 1999), chronic and acute rheumatic (Hussein 1985), prostate and other urinary tract diseases (Mosaddegh et al., 2012), and as antiviral and antioxidant (Sroka et al., 1994) in traditional medicine.

The pollen morphology of the Geraniaceae has been studied by many previous studies such as Erdtman (1952), Moore and Webb (1978), Oltmann (1967), Kuprianova and Alyoshina (1972), Hutchinson (1969) and Bortenschlager (1967). There are many taxonomical studies about Erodium species such as Raina (1985) carried out monographic studies of Geraniaceae family from Kashmir (India) and studied pollen and seed characters of E. cicutarium and $E$. tibetianura species. Ou and Kao (1994) analyzed general taxonomic and morphological properties of Erodium moschatum in Taiwan. Özbucak (1995) studied taxonomic and morphological characters of some Erodium species in Central Black Sea Region of Turkey. Parmaksız (1997) analyzed general pollen characters and pollen type of Erodium acaule, E. cucitarium and E. ciconium species in Tokat (Turkey). Shehata (2008) analyzed nine Erodium species in Egypt to find out the evidence of possible taxonomic significance. Naggar (2008) investigated seed morphology and seed coat sculpture of 14 native species of Erodium in Egypt and he emphasised that size, shape, epidermal cell patterns of seeds were important for taxonomic of Erodium species. Recently, several studies about morphology, autecology, conservation biology, caryology, fruit, seed and pollen micromorphology of $E$. somanum and $E$. pelargoniiflorum carried out by Oskay (2010; 2017), Oskay et al. $(2011 ; 2018)$. Ather et al. (2012) prepared palynology atlas of Pakistan and studied pollen morphology of E. cucitarium and E. malacoides species. Francis et al. (2012) studied general morphological, taxonomical, palinological properties of E. cucitarium in Canada.

Despite of many comprehensively studies which are carried out on morphological and taxonomical specifications of Erodium species, studies about palynological and seed micromorphological specifications of species are limited. Pollen and seed morphology are very important to characterize and classify any plant properly. The aim of the study is to expand morphological descriptions of studied species which includes their detailed pollen and seed specifications. These informations will be very useful for further studies on Erodium species. Also, these characters are also required for database preparation in this digital world by which further experiments or research will be done.

To the best our knowledge this is the first study about detailed micromorphology on pollen and seeds of E. amanum Boiss \& Kotschy and $E$. botrys (Cav.) Bertol species and their systematic implications.

\section{MATERIALS AND METHODS}

The study is based on pollen and seed morphology of seven wild Erodium species from Hatay province (Table 1). The study area is located in the East Mediterranean region $\left(35^{\circ} 48^{\prime}-37^{\circ} 00^{\prime} \mathrm{N}\right.$ latitude and $35^{\circ} 46^{\prime}-36^{\circ} 41^{\prime} \mathrm{E}$ longitude). It has a typical Mediterranean climate, with an annual average temperature of $18.1{ }^{\circ} \mathrm{C}$ and average annual rainfall of about 
$1.078 \mathrm{~mm}$, most of which falls during winter months. The temperatures varies $7-32{ }^{\circ} \mathrm{C}$ experienced during January and July respectively (Altay et al., 2016).

The examined seed and pollen samples were collected from their natural habitats (Table 1). The plant specimens have identified by using the keys in Flora of Turkey and The East Aegean Islands (Davis, 1967). All pollen grains for light microscope examination were prepared according to the standard procedure of Wodehouse (1935). In the palynological study, suitable samples were taken from these materials for SEM and light microscope (Olympus CX21FS1). Polar length (P), equatorial width
(E), P/E ratio, exhin and intin thickness, colpus and porus length (clg and plg), colpus and porus width (clt and plt) were measured on the average on 30 different pollen grains, and were assessed by the biometric method. Arithmetic means and standard deviations were also calculated. For SEM, pollen and seed samples were directly mounted on stubs. Samples were coated with gold in POLARON SC 7620 ionsputter and then observed by standard techniques using a scanning electron microscope (JEOL JSM-5500 LV). Erdtman (1952) and Punt et al. (2007) was used for pollen terninology and Barthlott (1981, 1984) was used for seed terminology.

Table 1. Localities of the studied Erodium taxa in Hatay province.

\begin{tabular}{|c|c|}
\hline Taxa & Locations \\
\hline E. acaule ( L.) Becherer \& Thell & Erzin district, İçmeler, road side 323 m. 15.03.2015 \\
\hline E. amanum Boiss \& Kotschy & Belen district, Atik plateau, rocky slopes 980 m. 05.07.2015 \\
\hline E. botrys (Cav.) Bertol & Yayladağı district, Kışlak, dry woodland, 715 m. 12.04.2015 \\
\hline Erodiım cicutarium ( L.) La'Herit subsp. cucitarium & Antakya district, Antakya Castle, grassland, 440 m. 14.04.2015 \\
\hline E. gruinum (L.) La'Herit & Yayladağı district, Yayladağı Barrage, rocky slopes, 800 m. 12.04.2015 \\
\hline E. malacoides (L.) La'Herit & Kırıkhan district, Alan plateau, rocky slopes, 1123 m. 02.04.2015 \\
\hline E. moschatum (L.) La'Herit & Kırıkhan district, Çataltepe, grassland, 180 m. 02.04 .2015 \\
\hline
\end{tabular}

\section{RESULTS AND DISCUSSION}

\section{Pollen morphology}

All palynological analysis has shown that the pollen grains are monad, isopolar, radially symmetrical. Pollen size measured as medium in the all species, while pollen shape found spheroidal and spheroidal-subprolate (Figure 1). According to our results, the biggest pollen size was found in E. gruinum $(99.98 \times 92.91 \mu \mathrm{m})$ and the smallest in E. moschatum $(55.75 \times 52.81$ $\mu \mathrm{m})$. The pollen shapes were generally spheroidal, those of in E. botrys, E. gruinum and E. moschatum taxa were spheroidal-subprolate. Their apertures were found to be tricolporate and equatorial views were circular and exine ornamentations were striate-reticulate in the all species (Figure 1). P/E ratio varied from 1.00 ( $E$. acaule) to 1.07 (E. gruinum). Exine thicknesses ranged from $3.53 \mu \mathrm{m}$ (E. amanum) to $4.32 \mu \mathrm{m}$ (E. gruinum); intine thicknesses ranged from $1.38 \mu \mathrm{m}$ (E. acaule) to $2.20 \mu \mathrm{m}$ (E. cicutarium subsp. cicutarium) respectively. The colpus lenght (clg) varied from $9.99 \mu \mathrm{m} \quad(E$. malacoides) to $25.12 \mu \mathrm{m}$ (E. gruinum); and colpus windth (clt) varied from $3.45 \mu \mathrm{m}(E$. cicutarium subsp. cicutarium) to $7.23 \mu \mathrm{m}$ ( $E$. gruinum). The porus lenght (plg) varied from $10.76 \mu \mathrm{m}$ (E. cicutarium subsp. cicutarium) to $16.66 \mu \mathrm{m}$ (E. botrys); and porus windth (plt) varied from $4.53 \mu \mathrm{m}$ (E. moschatum) to $8.97 \mu \mathrm{m}$ (E. botrys). Detailed results of palynological analyses were given in Table 2.

Raina (1985) determined that $E$. cucitarium had suboblate to oblatespheroidalpollen grains, while we have found that this species had only spheroidal pollen grains. Exine ornamentation were medium size, 
striate-reticulate surface. Similarly, Francis et al. (2012) reported that E. cucitarium had tricolporat and striate-reticulate surface and their results are similar to ours. Shehata (2008) studied pollen morphology of the Geraniaceae family from Egypt and similarly identified three types and three subtypes, based on the exine ornamentation. Although in that study it was reported that E. cucitarium, E. gruinum, $E$. malacoides and E.moschatum had prolatespheroidal pollen grains, we have found that $E$. cucitarium and E. moschatum spheroidal pollen grains, while E. gruinum and E. malacoides spheroidal-subprolate pollen grains. The study emphasised that, pollen size $(\mathrm{P} \times \mathrm{E})$ measured as
$5236 \mu \mathrm{m}$ in E. cucitarium, as $11766 \mu \mathrm{m}$ in $E$. gruinum, as $5159 \mu \mathrm{m}$ in E. malacoides and as $3360 \mu \mathrm{m}$ in E. moschatum. However, in our study E. cucitarium as $2994 \mu \mathrm{m}$, E. gruinum as $9290 \mu \mathrm{m}, E$. malacoides as $3394 \mu \mathrm{m}$ and $E$. moschatum as $2944 \mu \mathrm{m}$ were found to be smaller size. Also, they reported that these species had striate-reticulate surface and it is in agreement with our results. Our results are consistent with previous study. These results show that there are several pollen characters of taxonomic significance in Erodium. The main palynological differences have been found especially in the pollen size and shape.

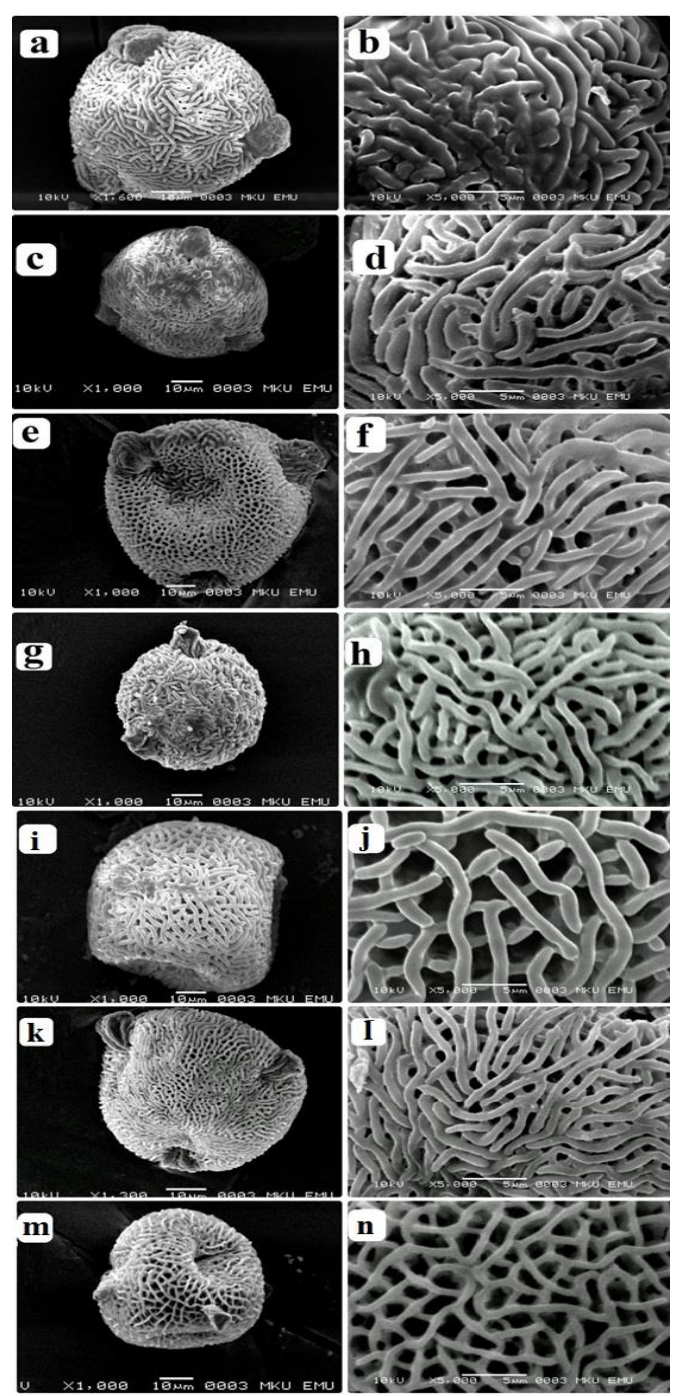

Figure 1. Pollen morphology of Erodium species (a-b: E. acaule, c-d: E. amanum, e-f: E. botyrs, g-h: E. cicutarium, i-j: E. grunium, k-1: E. malacoides, m-n: E. moschatum 
Table 2. Pollen morphological characters of the Erodium species studied.

\begin{tabular}{lccccccc}
\hline Taxa & E. acaule & $\boldsymbol{E}$. amanum & E. botrys & E. cicutarium & E. gruinum & E. malacoides & E. moschatum \\
\hline $\mathbf{P}(\boldsymbol{\mu m})$ & $55.55 \pm 3.64$ & $56.40 \pm 2.59$ & $69.66 \pm 3.93$ & $56.01 \pm 3.31$ & $99.98 \pm 4.01$ & $59.97 \pm 2.98$ & $55.75 \pm 3.16$ \\
$\mathbf{E}(\boldsymbol{\mu m})$ & $55.18 \pm 3.09$ & $55.02 \pm 2.57$ & $65.91 \pm 3.60$ & $53.47 \pm 3.42$ & $92.91 \pm 4.62$ & $56.58 \pm 3.32$ & $52.81 \pm 3.15$ \\
$\mathbf{P} / \mathbf{E}$ & 1.00 & 1.02 & 1.05 & 1.04 & 1.07 & 1.06 & 1.05 \\
Shape & $\mathrm{Sp}$ & $\mathrm{Sp}$ & Sp-Subpro & $\mathrm{Sp}$ & Sp-Subpro & Sp-Subpro & Sp \\
$\mathbf{C l g}(\boldsymbol{\mu m})$ & $11.15 \pm 1.12$ & $11.02 \pm 0.96$ & $10.76 \pm 0.82$ & $11.14 \pm 0.54$ & $25.12 \pm 3.20$ & $9.99 \pm 1.04$ & $11.27 \pm 1.41$ \\
$\mathbf{C l t}(\boldsymbol{\mu m})$ & $4.99 \pm 1.83$ & $6.50 \pm 7.34$ & $4.76 \pm 1.48$ & $3.45 \pm 0.54$ & $7.23 \pm 1.17$ & $3.84 \pm 0.77$ & $3.96 \pm 1.23$ \\
$\mathbf{P I g}(\boldsymbol{\mu m})$ & $11.53 \pm 1.08$ & $12.15 \pm 1.28$ & $16.66 \pm 2.35$ & $10.76 \pm 2.30$ & $11.91 \pm 0.54$ & $12.81 \pm 1.77$ & $11.60 \pm 0.79$ \\
$\mathbf{P I t}(\boldsymbol{\mu m})$ & $5.72 \pm 0,86$ & $5.61 \pm 0.74$ & $8.97 \pm 1.93$ & $5.38 \pm 2.03$ & $6.53 \pm 0.54$ & $6.15 \pm 0.66$ & $4.53 \pm 0.56$ \\
Exine $(\boldsymbol{\mu m})$ & $3.87 \pm 0.64$ & $3.53 \pm 0.83$ & $4.27 \pm 1.01$ & $4.26 \pm 0.72$ & $4.32 \pm 0.65$ & $3.98 \pm 0.90$ & $3.79 \pm 0.62$ \\
Intine $(\boldsymbol{\mu m})$ & $1.38 \pm 0.46$ & $1.65 \pm 0.41$ & $1.88 \pm 0.69$ & $2.20 \pm 0.62$ & $1.57 \pm 0.58$ & $1.79 \pm 0.50$ & $1.42 \pm 0.45$ \\
\hline $\mathbf{A b}$ & &
\end{tabular}

Abbreviations: $\mathrm{P}$ - polar axis; E - equatorial axis; $\mathrm{Clg}$ - length of colpi; Clt - width of colpi; Plg - length of porus; Plt width of porus; $\mathrm{Sp}$ - Spheroidal, Sp-Subpro - Spheroidal-subprolate

\section{Seed morphology}

The seeds dehisceing along with mericarps and seed surface of the all species were glabrous. The seed features of possible taxonomic importance in the examined taxa are given in Table 3. The seeds were 2.69 to $5.32 \mathrm{~mm}$ in length and 0.75 to $1.72 \mathrm{~mm}$ in width. Seed sizes varied greatly among the all species, with the smallest seeds in E. acaule $(2.95 \times 0.75 \mathrm{~mm})$, and the largest in E. amanum $(5.32 \times 1.69 \mathrm{~mm})$. Seed shape were found ovate-elliptic or oblanceolate. The seed coat surfaces of the examined taxa were determined as reticulatefoveate, rugose-foveate or bireticulate-foveate (Figure 2). The hilum were usually distinct and have basal position in all species. The periclinal wall of the cells is variously concave or flattened. The shape of the epidermal cells showed significant variation among the examined species. Rectangular cells in $E$. acaule, E. cucitarium and E. malacoides, squarepolygonal cells in E. gruinum and E. amanum, while polygonal cells observed in E. moschatum and E. botrys taxa (Figure 2).

In recent years, many workers studied seed morphology of Erodium species. For example, E. cucitarium described as conical seed shape, indistinct hilum, reticulate-areolate seed surface and elongate cell shape in Raina (1985); as narrow ovoid to oblanceolate seed shape, $3 \times 1$ $\mathrm{mm}$, brown color, foveate seed surface and polygonal cell shape in Naggar (1992); as obovate seed shape, $2.60-3.05 \times 0.85-1.10 \mathrm{~mm}$, dark brown, distinct hilum and scalariformreticulate seed surface in Parmaksiz (1997); as narrow ovoid seed shape, $3 \times 1 \mathrm{~mm}$ and light brown color in Francis et al. (2012); as oblanceolate seed shape, 2.6-3 × 0.6-1 mm, brown color, basal hilum and foveate seed surface in Ather et al. (2012). Similarly, we have found that this species had oblanceolate shape, $2.95 \times 0.90 \mathrm{~mm}$, brown color, basal hilum, reticulate foveate surface and rectangular cell shape.

Table 3. Seed morphological characters of the Erodium species studied.

\begin{tabular}{|c|c|c|c|c|c|c|}
\hline Taxa & Seed shape & Seed length $(\mathrm{mm})$ & $\begin{array}{l}\text { Seed width } \\
(\mathrm{mm})\end{array}$ & L/W seed & Seed surface & Cell shape \\
\hline E. acaule & Ovate-eliptic & $2.95 \pm 0.19$ & $0.75 \pm 0.14$ & 3.9 & Rugose-foveate & Rectangular \\
\hline E. amanum & Ovate-eliptic & $5.32 \pm 0.42$ & $1.69 \pm 0.20$ & 3.1 & Reticulate-foveate & Square-Polygonal \\
\hline E. botrys & Oblanceolate & $3.53 \pm 0.50$ & $0.75 \pm 0.20$ & 4.7 & Rugose-foveate & Polygonal \\
\hline E. cicutarium & Oblanceolate & $2.95 \pm 0.10$ & $0.90 \pm 0.12$ & 3.3 & Reticulate-foveate & Rectangular \\
\hline E. gruinum & Oblanceolate & $4.58 \pm 0.40$ & $1.72 \pm 0.31$ & 2.7 & Bireticulate-foveate & Square-Polygonal \\
\hline E. malacoides & Oblanceolate & $2.69 \pm 0.23$ & $0.83 \pm 0.12$ & 3.2 & Reticulate-foveate & Rectangular \\
\hline E. moschatum & Oblanceolate & $3.24 \pm 0.20$ & $0.89 \pm 0.12$ & 3.6 & Rugose-foveate & Polygonal \\
\hline
\end{tabular}



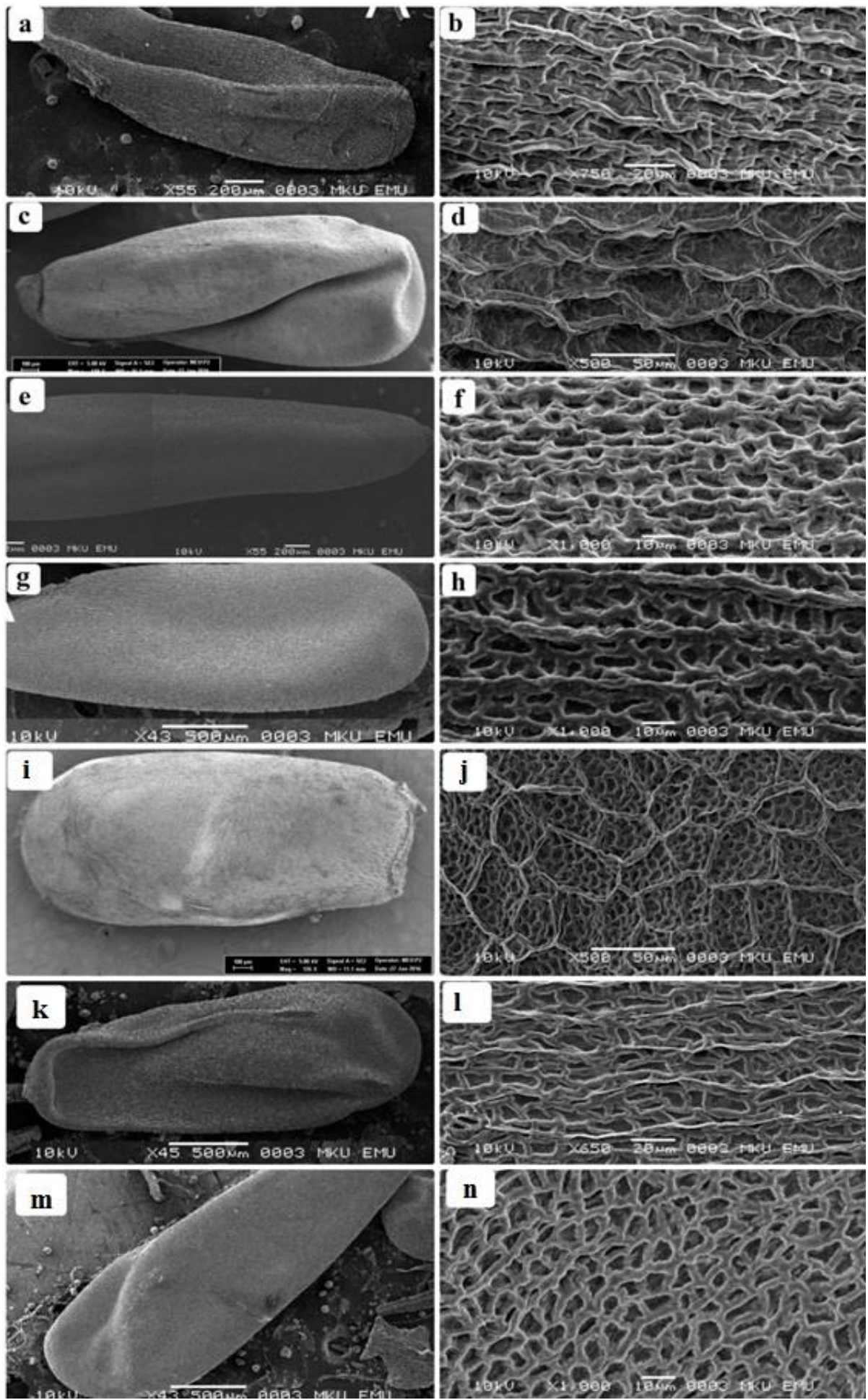

Figure 2. Seed micromorphology of Erodium species (a-b: E. acaule, c-d: E. amanum, e-f: E. botyrs, g-h: E. cicutarium, ij: E. grunium, k-1: E. malacoides, m-n: E. moschatum)

Parmaksiz (1997) reported that E. acaule had obovate shape, 2.3-2.7 $\times$ 0.7-0.9 $\mathrm{mm}$, brown color, distinct hilum, scalariform-reticulate surface while we have found that ovate-eliptic shape, $2.95 \times 0.75 \mathrm{~mm}$, brown color, distinct hilum, rugose foveate surface and rectangular cell shape. Our results are similar to his results except shape and surface of seed. Although, Naggar (1992) emphasised that E. grunium had obclavate or cylindrical seed shape, $5.5 \times 2 \mathrm{~mm}$, brown, reticulate seed surface and polygonal cell shape, E. moschatum had narrow obovate seed 
shape, $3 \times 0.9 \mathrm{~mm}$, brown, undulate seed surface and polygonal cell shape, and E. malacoides had obclavate or cylindrical seed shape, $5.5 \times 2 \mathrm{~mm}$, brown, reticulate seed surface and polygonal cell shape. Also, Ather et al. (2012) determined that E. malacoides had oblanceolate seed shape, 2.5$2.7 \times 0.7-0.8 \mathrm{~mm}$, dark brown, with basal hilum and scalariform seed surface. Similarly, the present study found that E. grunium had oblanceolate seed shape, $4.58 \times 1.72 \mathrm{~mm}$, brown, bireticulate-foveate seed surface and square-polygonal cell shape, E. moschatum had oblanceolate seed shape, $3.24 \times 0.89 \mathrm{~mm}$, brown, rugose-foveate seed surface and polygonal cell shape and E. malacoides had oblanceolate seed shape, $42.69 \times 0.83 \mathrm{~mm}$, brown, reticulate-foveate seed surface and rectangular cell shape.

These previous studies found data that could be useful in providing additional information for taxonomic delimitation at various levels in the genus. The findings of seed characteristics in this study are compared with the findings of seed characteristics by related previous studies, and it is seen that genus Erodium has its own distinct characters. These micromorphological characters like seed shape, size, surface ornamentation and epidermal cell patterns have revealed differences between Erodium species. Similarly, our results shown that seed size and surface ornamentation were significant characters of the investigated species. Our results are generally consistent with previous study.

This study is aimed to introduce pollen and seed micromorphological details of some Erodium species. The morphological characters of the investigated species were similar to those reported by various botanist in recent years. However, morphological findings including the pollen and seed features of E. amanum and $E$. botrys species was presented for the first time.

\section{ACKNOWLEDGMENTS}

This study was supported by Scientific Research Commission of Hatay Mustafa Kemal niversity (Project No: 11600). Conflict of Interest: The authors declare that there is no conflict of interest.

\section{REFERENCES}

Altay V, Karahan F, Öztürk M, Hakeem KR, Ilhan E, Erayman M, 2016. Molecular and Ecological Investigations on the Wild Populations of Glycyrrhiza L. Taxa Distributed in the East Mediterranean Area of Turkey. Journal of Plant Research, 129(6): 1021-1032.

Ather A, Abid R, Qaiser M, 2012. The Seed Atlas of Pakistan -VII. Geraniaceae. Pakistan Journal of Botany, 44(3):1059-1064.

Barthlott W, 1981. Epidermal and Seed Surface Characters of Plant: Systematic Applicability and Some Evolutionary Aspects. Nordic Journal of Botany, 1: 345-355.

Barthlott W, 1984. Microstructural Features of Seed Surfaces, In: Heywood, VH. \& Moore DM. (eds.): Current Concepts in Plant Taxonomy, Academic Press, pp. 95-105.

Baytop T, 1999. Türkiye' de Bitkilerle Tedavi 2. Ed. Nobel Tip Kitabevi, Istanbul, pp. 163.

Bortenschlager S. 1967. Vorlaufi ge Mitteilungen zur Pollenmorphologie in der Famile der Geraniaceae und ihre Systematische Bedeutung. Grana Palynology, 7: 400-468.

Davis PH, 1967. Erodium L'Hérit, In: Davis PH (ed): Flora of Turkey and the East Aegean Islands, Vol. 2. Edinburgh University Press, Edinburgh, pp. 475-487.

Davis PH, Mill RR, Tan K, 1988. Erodium L'Hérit. In: Davis, PH. Mill, RR. Tan, K. (eds): Flora of Turkey and the East Aegean Islands, Vol. 10. (Suppl. I.) Edinburgh University Press, Edinburgh, pp. 105-106.

Erdtman G, 1952. Pollen Morphologgy and Plant Taxonomy. Angiosperms. Chronica Botanica Co., Waltham, Massachusettes. 
Fiz O, Vargas P, Alarcón ML, Aldasoro JJ, 2006. Phylogenetic Relationships and Evolution in Erodium (Geraniaceae) Based on trnL-trnF Sequences. Systematic Botany, 31(4): 739763.

Francis A, Darbyshire SJ, Legere A, Simard MJ, 2012. Erodium cicutarium (L.) L'He' r. ex Aiton. The Biology of Canadian Weeds, 151, Canadian Journal of Plant Science, 92: 13591380.

Günenç M, 2015. Hatay'da Yayılış Gösteren Bazı Erodium L. (Geraniaceae) Türlerinin Anatomik, Morfolojik ve Palinolojik Özellikleri, Mustafa Kemal Üniversitesi, Fen Bilimleri Enstitüsü Biyoloji Bölümü, Yüksek Lisans Tezi (Basılmıș).

Güner A, Özhatay N, Ekim T, Başer KHC, 2000. Erodium L'Hérit. In: Güner, A. Özhatay, N. Ekim, T. Başer, KHC. (eds): Flora of Turkey and East Eagean Islands, Vol 11 (Suppl. II). Edinburgh University Press, Edinburgh, pp.7475.

Hussein FTK, 1985. Medicinal Plants in Libya, 1st ed., Arab Encyclopedia House, BeirutLebanon, p. 436.

Hutchinson J, 1969. Evoluation and Phylogeny of Flowering Plants. Academic Press, London.

Kuprianova LA, Alyoshina LA, 1972. Pollen and Spores of Plants from the Flora of European Part of USSR. Vol. I.. p. 170. Acad. Sci. U.S.S.R. Komarov. Bot. Inst

Moore PD, Webb JA, 1978. An Illustrated Guide to Pollen Analysis. Hodder and Stoughton, London.

Mosaddegh M, Naghibi F, Moazzeni H, Pirani A, S. Esmaeili S, 2012. Ethnobotanical Survey of Herbal Remedies Traditionally Used in Kohghiluyeh va Boyer Ahmad Province of Iran. Journal of Ethnopharmocology, 141(1): 80-95.

Naggar SE, 1992. Seed Morphology and Taxonomy of the Egyptian Species of Erodium L'HERIT.(Geraniaceae). Feddes Repertorium, 103: 345-350.

Oltmann O, 1967. Pollen MorphologischSystematische Urzersuchungen innerhalb der Geraniales. Dissert Botany, 11: 163.
Oskay DA, 2017. Morphological Study on Dioecious Endemic Erodium somanum H. Peşmen (Geraniaceae), critically endangered in Turkey. Acta Botanica Croatica, 76: 27-31.

Oskay D, Altan Y, Kesercioğlu T, 2011. Investigation of Pollen Features and Chromosome Numbers of Erodium somanum. Biodiversity and Conservation, 4(1): 186-190

Oskay D, Minareci E, Alçıtepe EA, 2018. Morphological Study on Endemic Erodium pelargoniiflorum (Geraniaceae), from Turkey. Celal Bayar Üniversitesi Fen Bilimleri Dergisi, 14(2): 251-255.

Ou JC, Kao MT, 1994. Erodium moschatum (L). L'Her. ( Geraniaceae ) A newly Naturalized plant for Taiwan. Taivania, Vol.38.

Özbucak S, 1995. Orta Karadeniz Bölgesinde bazı Erodium L'herit.(Geraniaceae) Türleri Üzerine Taksonomik Bir Çalışma, Ondokuz Mayıs Üniversitesi, Fen Bilimleri Enstitüsü Biyoloji Bölümü, Yüksek Lisans Tezi (Basılmış).

Parmaksız İ, 1997. Tokat İlinde Yayılış Gösteren Erodium L'Herit (Geraniaceae) Türleri Üzerinde Taksonomik ve Palinolojik Araştırmalar, Gaziosmanpaşa Üniversitesi Fen Bilimlerim Enstitüsü, Yüksek Lisans Tezi (Basılmıs).

Raina SK, 1985. Monographic Studies on Geraniaceae of Kashmir. University of Kashmir, India, Doctoral Thesis (Printed).

Shehata AA, 2008. Pollen morphology of Egyptian Geraniaceae: An assessment of taxonomic value. International Journal of Botany, 4: 6776.

Sroka Z, Bodalska HR, Mażol I, 1994. Antioxidative Effect of Extracts from Erodium cicutarium L. Z Naturforsch C.Nov-Dec;49(11-12): 881-884. Wodehouse RP, 1935. Pollen Grains. New York, Mc Graw-Hill Co. Press., 574 pp.

Y1ldırımlı Ş, Doğru-Koca A, 2004. A New Species from Turkey, Erodium aytacii Yıldırımlı \& A. Doğru-Koca (Geraniaceae), The Herb Journal of Systematic Bot 11: 1-6. 